3. Kantorovich L. V. (1992). Matematicheskiye metody organizatsii i planirovaniya proizvodstva [Mathematical methods of production organization and planning]. Leningrad: Leningradskiy gosudarstvennyu universitet. [in Russian].

4. Marshall A. (1993). Printsypy ekonomicheskoy nauki [Principles of Economics]. Moskva: Izdatelskaya gruppa Progress.

Vols. 3: Vol. 1. [in Russian].

5. Schumpeter J.A. (2011). Teoriia ekonomichnogo rozvytku: Doslidzhennia prybutkiv, kapitalu, kredytu, vidsotka ta ekonomichnogo tsyklu [The Theory of Economic Development: An Inquiry into Profits, Capital, Credit, Interest and the Business Cycle]. Kyiv: Vydavnychii dim "Kyievo-Mogylianska akademia”. [in Ukrainian].

6. Kablukov N. A. (1884). Vopros o rabochikh v selskom khoziaystve [The question of workers in agriculture]. Moskva: redaktsyia "Yuridicheskogo Vestnika". [in Russian].

7. Tracy M. (1963). Agriculture in Western Europe Crisis and adaption since 1880. London: J. Cape. [in English].

8. Skvortsov A. (1898). Osnovaniya politicheskoy ekonomii [Grounds for political economy]. Sankt-Peterburg: tipografiya I. Goldberga. [in Russian].

9. Yakovets Yu. V. (Eds.). (2003). Nobelevskiye laureaty po ekonomike: vzglyad iz Rossii [Nobel Laureates in Economics: A View from Russia]. Sankt-Peterburg: Izdatelstvo "Gumanistika". [in Russian].

10. Schultz T.W. (1978). On Economics and Politics of Agriculture. Bloomington: Indiana University Press. P. 3-23. [in English].

11. Schtefan fon Kramona-Taubadel, Demianenko S., Kaun A. (Eds.). (2004) Silske gospodarstvo Ukrainy: kryza ta vidnovlennia [Ukrainian agriculture: crisis and recovery]. Kyiv: Garant-Servis. [in Ukrainian].

12. Kaplan R.S., Norton D.P. (1992). The Balanced Scorecard as a strategic management system. Harvard Business Review. January-February. 61-66. [in English].

Рецензент д.е.н., професор Писаренко В.В.

УДК 330.11.001.76

Дячков Д.В., к.е.н., доцент

Простак О.С., Тенянко А.О., здобувачі вищої освіти СВО «Магістр»

Полтавська державна аграрна академія

\title{
НАПРЯМИ ПІДВИЩЕННЯ ЕФЕКТИВНОСТІ УПРАВЛІННЯ ІННОВАЦІЯМИ У СІЛЬСЬКОГОСПОДАРСЬКИХ ПІДПРИЕМСТВАХ
}

В статі охарактеризовано залежність сталого розвитку підприємств агропродовольчої сфери від результативності розробки, освоєння та поширення нововведень. Визначено найбільш загальну та широковживану класифікацію інновацій в агропродовольчій сфері за предметом та сферою застосування, відповідно до якої визначено чотири їх типи: селекційно-генетичні, виробничі, організаційно-управлінські та економічні, соціально-екологічні. Зважаючи на зазначені типи інновацій, охарактеризовано пріоритетні напрями активізації інноваційної діяльності в агропродовольчій сфері. Розроблено схему організаційноекономічного механізму інноваційного розвитку агропродовольчої сфери, основними складовими якого є: організаційно-економічна, інституційна, інструментальна, нормативно-правова, методична, соціальнопсихологічна та фінансово-економічна. Запропоновані стратегічні напрями підвищення ефективності управління інноваціями на сільськогосподарських підприємствах.

Ключові слова: аграрний комплекс, агроінновації, агропрдовольча сфера, ефективність, інновації, організаційно-економічний механізм, сільськогосподарське підприємство.

Diachkov D., Prostak O., Tenyanko A.

\section{DIRECTIONS OF INCREASING THE EFFICIENCY OF INNOVATION MANAGEMENT AT AGRICULTURAL ENTERPRISES}

The article describes the dependence of sustainable development of agro-food enterprises on the effectiveness of development and dissemination of innovations. The most common and widespread classification of innovations in the agro-food sector was defined by subject and scope, according to which four types were defined: breeding-genetic, industrial, organizational-managerial and economic, social-ecological. Considering these types of innovations, the priority directions of activation of innovative activity in the agro-food sphere were characterized. The scheme of organizational and economic mechanism of innovative development of agro-food sector has been developed, the main components of which are: organizational-economic, institutional, instrumental, normative-legal, methodical, social-psychological and financial-economic. Strategic directions for improving the efficiency of innovation management in agricultural enterprises were proposed. 
Key words: agricultural complex, agro-innovations, agro-food sphere, efficiency, innovations, organizational and economic mechanism, agricultural enterprise.

Дячков Д.В., Простак Е.С., Тенянко А.А.

\title{
НАПРАВЛЕНИЯ ПОВЫШЕНИЯ ЭФФЕКТИВНОСТИ УПРАВЛЕНИЯ ИННОВАЦИЯМИ НА СЕЛЬСКОХОЗЯЙСТВЕННЫХ ПРЕДПРИЯТИЯХ
}

\begin{abstract}
В статье охарактеризовано зависимость устойчивого развития предприятий агропродовольственной сферы от результативности разработки, освоения и распространения нововведений. Определено наиболее общую и часто используемую классификацию инноваций в агропродовольственной сфере по предмету и сфере применения, в соответствии с которой определено четыре их типа: селекционно-генетические, производственные, организационно-управленческие и экономические, социально-экологические. Учитывая указанные типы инноваций, охарактеризовано приоритетные направления активизации инновационной деятельности в агропродовольственной сфере. Разработана схема организационноэкономического механизма инновационного развития агропродовольственной сферы, основными составляющими которого являются: организационно-экономическая, институциональная, инструментальная, нормативно-правовая, методическая, социально-психологическая и финансовоэкономическая. Предложены стратегические направления повышения эффективности управления инновациями на сельскохозяйственных предприятиях.

Ключевые слова: аграрный комплекс, агроинновация, агропродовольственная сфера, эффективность, инновации, организационно-экономический механизм, сельскохозяйственное предприятие.
\end{abstract}

Постановка проблеми у загальному вигляді з її важливими науковими та практичними завданнями. Сталий розвиток підприємств агропродовольчої сфери (АПС) залежить від результативності розробки, освоєння та поширення нововведень. Особливу роль при цьому набуває ефективність управління інноваційною діяльністю, яка є найважливішою складовою розвитку сільськогосподарського виробництва та стає основою переходу АПС на інноваційний шлях. Більшість підприємств, які впроваджують у виробництво наукові досягнення, домагаються істотного поліпшення виробничих та економічних показників. Перш за все, це зростання врожайності сільськогосподарських культур та продуктивності в тваринництві. Передові агропідприємства різних регіонів досягають двох-, трьох-, та навіть чотириразового зростання врожайності та виробництва продукції тваринного походження $[8,10]$.

Для досягнення поставлених завдань забезпечення ефективного управління інноваційним розвитком необхідна реалізація багатопланових заходів інноваційного характеру, які забезпечують істотне нарощування виробництва сільськогосподарської продукції, розширення іï асортименту та підвищення якості до вимог світових стандартів. Зазначене, в свою чергу, потребує формування новітніх механізмів господарювання на основі вдосконалення організації галузі, впровадження інноваційних технічних засобів та технологій виробництва продукції рослинництва й тваринництва для суттєвого підвищення економічної ефективності сільськогосподарського виробництва [3].

Враховуючи багатоаспектність застосування в теорії та практиці підходів й інструментів інноваційної діяльності в аграрному секторі, враховуючи тенденції глобалізації та міжнародної інтеграції, виникає необхідність визначення сучасних напрямів підвищення ефективності управління інноваціями на сільськогосподарських підприємствах.

Аналіз останніх досліджень, у яких започатковано вирішення проблеми. Питанням, пов'язаними із визначення стану, проблем та перспектив розвитку інноваційної діяльності в АПС присвячені напрацювання вітчизняних та зарубіжних 
вчених та практиків, зокрема: Березіної Л.М., Буніна М.С., Ейдіа О.Л., Гнатьєвої Т.М., Гончаренко О.В., Крюкової І.О., Лупенко Ю.О., Скринника Є., Федоренка В.Ф., Буклагіна Д.С., Аронова Е.Л. та ін. Однак, підкреслюючи значимість виконаної роботи як вітчизняними, так і зарубіжними вченими, необхідно відзначити відсутність комплексних досліджень 3 розробки методичних та практичних рекомендацій інноваційного розвитку сільськогосподарських підприємств та АПС в цілому.

Цілі статті. Фрагментарність досліджень зазначеного предметного поля та окреслена наукова проблема визначила мету, яка полягає у визначенні напрямів підвищення ефективності управління інноваціями на сільськогосподарських підприємствах.

Виклад основного матеріалу дослідження 3 повним обгрунтуванням отриманих наукових результатів. Стан інноваційної діяльності в аграрній сфері України зумовлений довгостроковим негативним впливом загальноекономічних проблем, пов'язаних зі структурною деформованістю галузі, домінуванням у ній виробництва продукції з низьким рівнем доданої вартості. Внаслідок неврегульованості питань комерціалізації та введення в господарський обіг результатів інтелектуальної діяльності з урахуванням оптимального поєднання інтересів бізнесу й держави обсяги нематеріальних активів у сільськогосподарських підприємствах не перевищують 2,5\% загальної вартості активів, тоді як в СС у середньому цей показник на рівні $50 \%$. Вихід сільського господарства на траєкторію сталого економічного зростання залежить від реалізації комплексу заходів, що передбачають максимальне використання та прискорене освоєння сучасних технологій, перехід галузі на інноваційну модель розвитку. Це зумовлює необхідність створення соціально-економічних, організаційних і нормативно-правових умов, що забезпечують ефективне відтворення, розвиток та використання науково-технічного потенціалу, належну організацію сучасної системи трансферу технологій, виробництва й реалізації нових видів конкурентоспроможної наукоємної продукції [7].

Найважливіша складова сталого економічного зростання в АПС - перехід від інерційної до інноваційної моделі господарювання. В сучасних умовах інноваційний шлях розвитку сільського господарства має три взаємопов'язаних і взаємообумовлених напрями $[5,11]$ :

інновації в людський фактор, що можливо за умови пріоритетного розвитку освіти, фундаментальних та прикладних науково-дослідних організацій, які розробляють нововведення, створення банку даних інновацій, а також інформаційної системи, яка обслуговує підприємства аграрного сектору;

інновації в біологічний фактор, пов'язані з розробкою та освоєнням нововведень, які забезпечують підвищення родючості грунту, зростання врожайності сільгоспкультур та продуктивності тварин. Саме особлива роль інновацій в біологічний фактор $є$ відмінною рисою інноваційного шляху розвитку сільського господарства в порівнянні 3 іншими секторами економіки;

інновації технологічного характеру, які забезпечують вдосконалення технікотехнологічного потенціалу галузі на основі застосування енерго- та ресурсозберігаючої техніки, наукоємних технологій. При цьому, особливого значення набуває розвиток галузей економіки, які забезпечують сільське господарство засобами виробництва.

Аналіз літературних джерел дозволив визначити найбільш загальну та широковживану класифікацію інновацій в АПС за предметом та сферою застосування, відповідно до якої доцільне видалення чотирьох їх типів: селекційно-генетичні, виробничі, організаційно-управлінські та економічні, соціально-екологічні (табл. 1). 
Таблиця 1.

Основні типи інновацій в агропродовольчій сфері $[1,4,12]$

\begin{tabular}{|c|c|c|c|}
\hline Селекційно-генетичні & $\begin{array}{c}\text { Технологічні й } \\
\text { виробничі }\end{array}$ & $\begin{array}{c}\text { Організаційно- } \\
\text { управлінські та економічні }\end{array}$ & $\begin{array}{c}\text { Соціальні та } \\
\text { екологічні }\end{array}$ \\
\hline $\begin{array}{l}\text { - нові сорти і гібриди } \\
\text { сільськогосподарських } \\
\text { рослин; } \\
\text { - нові породи, типи } \\
\text { тварин і кроси птиці; } \\
\text { - виведення рослин і } \\
\text { тварин, стійких до } \\
\text { хвороб і шкідників, } \\
\text { несприятливих факторів } \\
\text { навколишнього } \\
\text { середовища. }\end{array}$ & $\begin{array}{l}\text { - розробка і } \\
\text { використання нової } \\
\text { техніки; } \\
\text { - нові технології } \\
\text { обробітку } \\
\text { сільськогосподарських } \\
\text { культур; } \\
\text { - нові індустріальні } \\
\text { технології в } \\
\text { тваринництві; } \\
\text { - науковообгрунтовані } \\
\text { системи землеробства і } \\
\text { тваринництва; } \\
\text { - нові форми технічного } \\
\text { обслуговування і } \\
\text { забезпечення ресурсами } \\
\text { АПС; } \\
\text { - нові добрива та їх } \\
\text { системи; } \\
\text { - нові засоби захисту } \\
\text { рослин; } \\
\text { - біологізації і } \\
\text { екологізація } \\
\text { землеробства; } \\
\text { - нові } \\
\text { ресурсозберігаючі } \\
\text { технології виробництва і } \\
\text { зберігання харчових } \\
\text { продуктів, спрямовані на } \\
\text { підвищення споживчої } \\
\text { цінності продуктів } \\
\text { харчування. }\end{array}$ & $\begin{array}{l}\text { - розвиток кооперації і } \\
\text { формування інтегрованих } \\
\text { структур в АПС; } \\
\text { - нові форми організації і } \\
\text { мотивації праці; } \\
\text { - нові форми організації і } \\
\text { управління в АПС; } \\
\text { - маркетинг інновацій; } \\
\text { - створення інноваційно- } \\
\text { консультаційних систем в } \\
\text { сфері науково-технічної та } \\
\text { інноваційної діяльності; } \\
\text { - концепції, методи } \\
\text { вироблення рішень; } \\
\text { - форми і механізми } \\
\text { інноваційного розвитку } \\
\text { формування системи } \\
\text { кадрів науково-технічного } \\
\text { забезпечення АПС. }\end{array}$ & $\begin{array}{l}\text { - поліпшення } \\
\text { умов праці, } \\
\text { вирішення } \\
\text { проблем охорони } \\
\text { здоров'я, освіти і } \\
\text { культури } \\
\text { трудівників села; } \\
\text { - оздоровлення та } \\
\text { поліпшення якості } \\
\text { навколишнього } \\
\text { середовища; } \\
\text { - забезпечення } \\
\text { сприятливих } \\
\text { екологічних умов } \\
\text { для життя, праці і } \\
\text { відпочинку } \\
\text { населення. }\end{array}$ \\
\hline
\end{tabular}

Зважаючи на зазначені основні типи інновацій, активізація інноваційної діяльності в АПС в сучасних умовах повинна здійснюватися по найбільш пріоритетних напрямів розвитку цього процесу, зокрема:

$\checkmark$ формування організаційно-економічних основ розвитку інноваційноконсультаційної діяльності в АПС;

$\checkmark$ створення організаційно-економічного механізму інноваційного розвитку АПС;

$\checkmark$ забезпечення нормативно-правового регулювання земельних відносин та форм земельної власності;

$\checkmark$ застосування ефективних біотехнологій створення нових форм культурних рослин та вихідного матеріалу для селекції з високою продуктивністю й стійкістю до несприятливих факторів середовища (трансгенні форми рослин); 
$\checkmark$ нові генотипи рослин з господарсько-цінними ознаками;

$\checkmark$ управління продукційним процесом та потенціалом агроекосистем та агроландшафтів;

$\checkmark$ прогнозування на основі удосконалення традиційних методів з використанням інформаційних та комп’ютерних технологій;

$\checkmark$ створення нових генотипів тварин, птахів, риб та корисних комах 3 господарсько-цінними ознаками (трансгенні форми тварин, птахів, риб та комах);

$\checkmark$ забезпечення безпеки та протидія біологічному тероризму;

$\checkmark$ дослідження процесів енергозабезпечення та енерго-, ресурсозбереження, поновлюваних джерел енергії;

$\checkmark$ дослідження інтенсивних машинних технологій та нової енергонасиченої техніки для виробництва продовольства;

$\checkmark$ забезпечення безпеки та контроль якості сільськогосподарської сировини й харчових продуктів;

$\checkmark$ розробка біотехнологічних й мембранних процесів переробки сільськогосподарської сировини;

$\checkmark$ застосування новітніх технологій виробництва продуктів для профілактичного, лікувального, дитячого та дієтичного харчування;

$\checkmark$ створення систем агроекологічного моніторингу;

$\checkmark$ сучасні технології зберігання й транспортування продовольчої сировини і харчових продуктів [12].

Модернізація аграрного комплексу повинна здійснюватися під впливом адаптивного організаційно-економічного механізму, спрямованого на створення науково-технологічній, управлінських та організаційних умов інноваційного розвитку галузі. Дослідження даного механізму дозволяє сформувати наступний його зміст (рис. 1).

Принципова схема організаційно-економічного механізму інноваційного розвитку АПС являє собою сукупність форм та методів здійснення інноваційної діяльності, взаємно і узгоджено функціонуючих та забезпечуючи вирішення основного завдання щодо забезпечення інноваційного розвитку галузі. Складовими організаційноекономічного механізму $є$ інституційна, інструментальна, нормативно-правова, методична, соціально-психологічна та фінансово-економічна.

Ефективне функціонування організаційно-економічного механізму інноваційного розвитку АПС потребує розвитку аграрної науки та активізації інноваційного підприємництва в галузі, що зумовлює необхідність вдосконалення системи планування та прогнозування в цій сфері діяльності, що в свою чергу потребує:

визначення низькозатратних напрямів, створення та освоєння інновацій безпосередньо в виробництві;

інтеграція аграрної науки безпосередньо в структуру аграрних ринків, що потребує державної підтримки дослідно-виробничих господарств, наукових організацій;

розробка та вдосконалення нормативно-правового забезпечення інноваційної діяльності сільськогосподарських підприємств;

\begin{tabular}{|c|c|c|c|}
\hline $\begin{array}{l}\text { Венчурні фонди, } \\
\text { біржі }\end{array}$ & $\begin{array}{c}\text { Міністерство аграрної } \\
\text { політики та продовольства } \\
\text { України }\end{array}$ & $\begin{array}{c}\text { Департамент інноваційної } \\
\text { діяльності та трансферу } \\
\text { технологій }\end{array}$ & $\begin{array}{l}\text { Міжнародні } \\
\text { об’єднання }\end{array}$ \\
\hline 4 & 조 & 소 & $\mathbf{A}$ \\
\hline \multicolumn{2}{|c|}{$\begin{array}{c}\text { Державні фінансові та кредитні } \\
\text { установи }\end{array}$} & \multicolumn{2}{|c|}{$\begin{array}{c}\text { Структурні підрозділи інноваційної } \\
\text { інфраструктури АПС }\end{array}$} \\
\hline
\end{tabular}


Рис. 1. Схема організаційно-економічного механізму інноваційного розвитку АПС [розроблено авторами на основі $3,4,6,9,12$ ]

стимулювання суб'єктів, що впроваджують інноваційні технології, шляхом проведення гнучкої державної податкової та цінової політики в сфері реалізації наукомісткої продукції [2];

створення дієвих механізмів стимулювання інноваційної активності, системи інституційних перетворень, захисту інформаційних систем в інноваційній сфері та введення ії в господарський оборот;

створення системи комплексної підтримки інноваційно-консультаційної діяльності, розвитку виробництва, підвищення конкурентоспроможності та експорту наукомісткої продукції;

розвиток інфраструктури інноваційної інфраструктури АПС, включаючи системи інформаційного забезпечення, експертизи, фінансово-економічного забезпечення, 
виробничо-технологічної підтримки, сертифікації та просування розробок, та перепідготовки кадрів;

розвиток малого інноваційного підприємництва шляхом формування сприятливих умов для створення та ефективного функціонування малих високотехнологічних організацій, надання державної підтримки на початковому етапі діяльності;

вдосконалення конкурсної системи відбору інноваційних проектів і програм;

реалізація критичних технологій та пріоритетних напрямків, здатних модернізувати АПС.

вдосконалення організаційних форм управління ефективністю інноваційної діяльності в АПС;

підвищення рівня керованості, розвиток інноваційного менеджменту в АПС; $13,14]$.

розробка та здійснення програм розвитку інноваційного забезпечення АПС [1, 6,

Висновки. Визначені особливості інновацій в аграрному секторі, розроблена схема організаційно-економічного механізму організації взаємодії складових інноваційного розвитку АПС та пропоновані заходи забезпечення його ефективного застосування дозволили сформувати стратегічні напрями підвищення ефективності управління інноваціями на сільськогосподарських підприємствах. Організаційно-економічний механізм інноваційного розвитку АПС повинен являти собою систему взаємопов'язаних форм і способів організації та стимулювання НДДКР, розвитку бізнесу в науковотехнічній сфері аграрного сектору, державної підтримки на всіх стадіях процесу (створення, поширення, впровадження і освоєння агроінновацій) на основі взаємного партнерства його учасників 3 метою підвищення соціально-економічного та інноваційного розвитку сільськогосподарського виробництва. Отримані результати стали основою для подальшого дослідження, яке полягає у формування ефективної системи управління інноваціями на сільськогосподарських підприємствах.

\section{Список бібліографічного опису:}

1. Березіна Л.М. Інноваційна політика підприємств АПК : тактичні і стратегічні аспекти. Маркетинг і менеджмент інновацій. 2013. № 4. C. 121-127.

2. Бунин М. С., Эйдис А. Л. Научные и практические проблемы инновационных процессов в АПК. М. : ФГНУ «Росинформагротех», 2005. $244 \mathrm{c}$.

3. Гнатьєва Т.М. Шляхи здійснення трансферу інновацій в аграрному секторі. Збірник матеріалів Міжнародної науковопрактичної інтернет-конферениї̈ «Проблеми розвитку глобальної економіки в умовах глобалізації». Харків : ХНТУСГ «Смугаста типографія», 2016. С. 91-94.

4. Гончаренко О.В. Інституціональні аспекти реалізації інноваційних пріоритетів розвитку агропромислового виробництва. Економіка. Управління. Інноваиії. Серія: Економічні науки. 2016. №1. ULR: http://nbuv.gov.ua/UJRN/eui_2016_1_5. (дата звернення: 04.09.2019).

5. Готра В.В. Сучасний стан та проблеми інноваційного розвитку аграрного сектору України. Актуальні проблеми економіки. 2014. №6 (156). C. 79-84.

6. Крюкова І.О. Формування механізму реалізації інноваційного потенціалу бізнес-суб'єктів сфери агропромислового виробництва. Всеукраӥнський науковий журнал «Актуальні проблеми інноваційної економіки». 2016. №2. С. 27-35.

7. Лупенко Ю.О. Пріоритетні напрями інноваційної діяльності в аграрній сфері України. Економіка АПК. 2014. №12. С. 5-11.

8. Организация инновационного развития сельского бизнеса в регионе. М. : ФГНУ «Росинформагротех», 2007. $292 \mathrm{c}$.

9. Сидельников А.Г. Стимулирование инновационного развития АПК. Российское предпринимательство. 2012. №8(206). С. 120125.

10. Скрынник Е. Технико-технологическая модернизация сельского хозяйства - важнейшая задача государственной агропродовольственной политики. Экономика сельського хозяйва России. 2010. № 1. С. 18-40.

11. Ушачев И. Экономический рост и конкурентоспособность сельского хазяйства Российской Федерации. АПК : экономика и управление. 2009. № 3. С. 17-30.

12. Федоренко В.Ф., Буклагин Д.С., Аронов Э.Л. Инновационная деятельность в АПК: состояние, проблемы, перспективы: науч. изд. М. : ФГНУ «Росинформагротех», 2010. 280 с.

13. Агробізнес індекс (ABI). Український клуб аграрного бізнесу: Офіційний сайт. ULR: http://ucab.ua/ua/ukab_proponue/abi. (дата звернення: 10.09.2019).

14. Офіційний сайт Міністерства аграрної політики та продовольства. ULR: http://minagro. gov.ua (дата звернення: 02.09.2019).

\section{References:}

1. Berezina, L. M. (2013). Innovatsiyna polityka pidpryyemstv APK : taktychni i stratehichni aspekty. [Innovative policy of agricultural enterprises: tactical and strategic aspects]. Marketynh i menedzhment innovatsiy - Marketing and innovation management, 4, 121-127 [in Ukrainian]. 
2. Bunin, M. S., Eidis, A. L. (2005). Nauchnyye i prakticheskiye problemy innovatsionnykh protsessov v APK [Scientific and practical problems of innovative processes in agroindustrial complex]. Moskwa: FGNU «Rosinformagrotekh» - Moscow: FSU "Rosinformagrotech", 244 [in Russian].

3. Hnat'yeva, T. M. (2016). Shlyakhy zdiysnennya transferu innovatsiy v ahrarnomu sektori [Ways of implementation of innovation transfer in the agricultural sector]. Zbirnyk materialiv Mizhnarodnoyi naukovo-praktychnoyi internet-konferentsiyi «Problemy rozvytku hlobal'noyi ekonomiky v umovakh hlobalizatsiyi» [Collection of materials of the International scientific and practical Internet conference "Problems of development of the global economy in the conditions of globalization"]. Kharkiv: KHNTUS·H - Kharkiv : KHNTUS·H «Smuhasta typohrafiya», 91-94 [in Ukrainian].

4. Honcharenko, O. V. (2016). Instytutsional'ni aspekty realizatsiyi innovatsiynykh priorytetiv rozvytku ahropromyslovoho vyrobnytstva [Institutional aspects of the implementation of innovative priorities for the development of agro-industrial production]. Ekonomika. Upravlinnya. Innovatsiyi. Seriya: Ekonomichni nauky - Economy. Management. Innovation. Series: Economic Sciences. [E-Reader Version]. Retrieved from: http://nbuv.gov.ua/UJRN/eui 2016 1 5. [in Ukrainian]

5. Hotra, V. V. (2014). Suchasnyy stan ta problemy innovatsiynoho rozvytku ahrarnoho sektoru Ukrayiny [The current state and problems of innovative development of the agrarian sector of Ukraine]. Aktual'ni problemy ekonomiky. - Current problems of the economy, 6(156), 79-84 [in Ukrainian]

6. Kryukova, I. O. (2016). Formuvannya mekhanizmu realizatsiyi innovatsiynoho potentsialu biznes-sub"yektiv sfery ahropromyslovoho vyrobnytstva [Formation of the mechanism of realization of innovative potential of business entities in the field of agro-industrial production]. Vseukrayins'kyy naukovyy zhurnal «Aktual'ni problemy innovatsiynoyi ekonomiky» - Ukrainian scientific journal "Actual problems of innovative economy", 2, 27-35 [in Ukrainian].

7. Lupenko, Yu. O. (2014). Priorytetni napryamy innovatsiynoyi diyal'nosti v ahrarniy sferi Ukrayiny [Priority directions of innovative activity in the agrarian sphere of Ukraine]. Ekonomika APK - APK economy, 12, 5-11 [in Ukrainian].

8. Organizatsiya innovatsionnogo razvitiya sel'skogo biznesa $\mathrm{v}$ regione [Organization of innovative development of rural business in the region]. (2008). Moskwa: FGNU «Rosinformagrotekh» - Moscow: FSU "Rosinformagrotech", 292 [in Russian].

9. Sidel'nikov, A. G. (2012). Ctimulirovaniye innovatsionnogo razvitiya [Stimulation of the innovative development of the agro-industrial complex APK]. Rossiyskoye predprinimatel'stvo - Russian entrepreneurship, 8(206), 120-125 [in Russian].

10. Skrynnik, Ye. (2010). Tekhniko-tekhnologicheskaya modernizatsiya sel'skogo khozyaystva - vazhneyshaya zadacha gosudarstvennoy agroprodovol'stvennoy politiki [Technical and technological modernization of agriculture - the most important task of the state agri-food policy]. Ekonomika sel's'kogo khozyayva Rossii - The economy of the rural economy of Russia, 1, 18-40 [in Russian].

11. Ushachev, I. (2009). Ekonomicheskiy rost i konkurentosposobnost' sel'skogo khozyaystva Rossiyskoy Federatsii [Economic growth and agricultural competitiveness of the Russian Federation]. APK: ekonomika i upravleniye - AIC: economics and management, 3, 17-30 [in Russian].

12. Fedorenko, V. F., Buklagin, D. S., Aronov, E. L. (2010). Innovatsionnaya deyatel'nost' v APK: sostoyaniye, problemy, perspektivy: nauch. izd. [Innovative activity in the agricultural sector: state, problems, prospects: scientific. ed.]. Moskwa: FGNU «Rosinforma grotekh» - Moscow: FSU "Rosinformagrotech", 280 [in Russian].

13. Ahrobiznes indeks (AVI). Ukrayins'kyy klub ahrarnoho biznesu: Ofitsiynyy sayt [Agribusiness Index (AVI). Ukrainian Agrarian Business Club: Official Website]. [E-Reader Version]. Retrieved from: http://ucab.ua/ua/ukab_proponue/abi. [in Ukrainian].

14. Ofitsiynyy sayt Ministerstva ahrarnoyi polityky ta prodovol'stva [Official Website of the Ministry of Agrarian Policy and Food]. [E-Reader Version]. Retrieved from:http://minagro.gov.ua [in Ukrainian]

Рецензент д.е.н., професор Маркіна I.A.

УДК 339.71

Ковальська Л.Л., д.е.н., професор, завідувач кафедри підприємництва, торгівлі та біржової діяльності Луцького національного технічного університету

\section{ПІДПРИЕМНИЦЬКИЙ ПОТЕНЦІАЛ ПІДПРИЕМСТВА: ЕКОНОМІЧНА СУТНІСТЬ ТА МЕТОДИКА ОЦІНКИ}

У статті проведено дослідження сутнісної характеристики поняття «підприємницький потенціал». Виділено три підходи до сутнісної характеристики підприємницького потенціалу підприємства: як сукупність ресурсів та здатність їх трансформувати у результат; як індивідуальні характеристики підприємця; як сукупність бізнес-ідей. Подано авторське бачення змісту поняття «підприємницький потенціал» підприємства. Подано авторський підхід до структуризації підприємницького потенціалу підприємства, який включає ресурсний потенціал, інтелектуальний потенціал та інноваційний потенціал. Розроблено методику аналізу та оцінки підприємницького потенціалу підприємства. Наведено характеристику етапів методики аналізу та оцінки підприємницького потенціалу підприємства.

Ключові слова: потенціал, підприємницький потенціал, ресурсний потенціал, інтелектуальний потенціал, інноваційний потенціал, підприємець, підприємство.

Kovalska L.

\section{ENTREPRENEURSHIP POTENTIAL OF THE ENTERPRISE: ECONOMIC NATURE AND EVALUATION METHODS}

The article studies the essential characteristics of the concept of «entrepreneurial potential». Three approaches to the essential characteristics of the entrepreneurial potential of the enterprise are identified: as a set 